\title{
Dopad procesu europeizace na vzdělávání a vzdělávací politiku České republiky
}

\section{The process of Europeanization and its Impact on Education and Educational Policy in the Czech Republic}

\section{Leona Šteigrová}

\begin{abstract}
This article deals with the issue of Europeanization and its impact on educational policy in the Czech Republic. The article begins with a focus on the theoretical background concerning the concept of Europeanization - especially its definition as a process of the creation of new institutions and their interactions with national (or possibly regional and local) institutions. Afterwards I address the main aspects of educational policy at the national level and development in this field within the European cooperation. The main part of the study is focused on the development and implications of the Bologna process, and of the impact of the European Union and its structures on the institutions and policy in the Czech Republic. It is possible to follow the progressive changes within the institutions responsible for European cooperation in the field of education in CR and also the impact of national policy on education. Although educational policy is entirely under the jurisdiction of nation states, the impact of European integration in this field is really far-reaching.
\end{abstract}

KEY WORDS Education, educational policy, European cooperation, Europeanization, Lisbon strategy

\section{1. Úvod}

V posledních několika letech se na mnoha platformách diskutuje problematika europeizace, zejména pak z hlediska vzájemných interakcí mezi institucemi a strukturami vytvořenými na úrovni Evropské unie a národních států, včetně konkrétních vlivů a dopadů, které tyto interakce přinášejí. Vzhledem k prohlubování evropské integrace a rozšiřování Evropské unie o nové členské státy se výzkum procesu europeizace velice rychle stal jedním ze široce sledovaných témat, zejména $\mathrm{v}$ rámci většiny společenskovědních oblastí. Rozšiřující se působnost evropských struktur postupně vytváŕí sít' vazeb, v nichž se identifikování všech proměnných a označení příčin a důsledků jednotlivých iniciativ stává stále komplikovanější záležitostí. Skutečnost, že působení evropských institucí se neustále rozšiřuje předkládáním nových a nových iniciativ, dodává celému procesu výrazný rys dynamičnosti, a tím i zvyšuje atraktivnost jeho sledování.

Tento článek by měl být v konkrétní rovině zaměřen na oblast vzdělávání a vzdělávací politiky České republiky. Jeho hlavním aspektem je otázka vlivu rozvíjející se evropské

Sociální studia. Fakulta sociálních studií Masarykovy univerzity, 3/2007. S. 89-105. ISSN 1214-813X. 
spolupráce na podobu vzdělávací politiky v České republice a dopadu vzájemných interakcí odehrávajících se zejména mezi národní a „evropskou“ rovinou. Právě vzdělávání, respektive vzdělávací politika, je jednou z velmi zajímavých oblastí pro výzkum otázky europeizace. Ačkoli pozornost bude věnována i vlivu jiných struktur a institucí nežli jen Evropské unii, zejména zapojení České republiky do Boloňského procesu, členství České republiky v EU s sebou přináśí velmi zásadní dopad na tuto politiku na národní úrovni. Z hlediska vlivu Evropské unie je přitom nutné mít na paměti, jaké kompetence má v tomto směru EU, nebot' dle primárního práva jsou kompetence institucí EU omezeny na podporu vzájemné spolupráce, která je pro členské státy žádoucí, případně jejíž kořeny lze legislativně podložit jinými politickými oblastmi. Z jistého pohledu by se tak dalo očekávat, že proces europeizace zde bude omezenější (pokud vůbec sledovatelný). I přesto je možné dopad europeizace detailně sledovat, jeho míra může být $\mathrm{v}$ některých př́ípadech překvapivá. Neméně zajímavá je i skutečnost, jakým způsobem jsou právně podloženy (legitimizovány) jednotlivé kroky evropských institucí při rozvíjení svých aktivit, a tím i působnosti.

\section{Teoretický koncept procesu europeizace}

V současné době jsme si již zvykli pracovat s pojmem europeizace ${ }^{l}$ stejně, jako s ostatními pojmy používanými zejména $\mathrm{v}$ oblasti evropské integrace a mezinárodních vztahů obecně. Přestože byl tento pojem ještě před zhruba deseti lety méně užívaným a pouze užší skupina badatelů věnovala pozornost všem aspektům rozvíjející se evropské integrace a jejího vlivu na interakce členských států ES/EU (tzn. v užším smyslu europeizace), v posledních několika letech se této problematice začala věnovat velká pozornost (srovnej Dančák, Fiala a Hloušek 2005: 12). Řada autorů se v poslední době zaměřila na zkoumání takových změn $\mathrm{v}$ rámci členských států EU, které jsou více či méně ovlivněny právě Evropskou unií, jejími institucemi a samotným působením v jednotlivých oblastech politiky. Ačkoli se studiu procesu europeizace již věnuje i řada českých textů, klíčovým zdrojem pro řádné pojetí europeizace jsou stále díla zahraničních autorů, kteří se zkoumáním tohoto procesu zabývají již delší dobu. Je $\mathrm{v}$ tomto prípadě nutné podotknout, že právě studium europeizace je jednou z oblastí, kde moderní informační technologie prokázaly svou funkčnost a efektivitu. Vzhledem $\mathrm{k}$ dynamičnosti tohoto procesu se většina klíčových a současně aktuálních zdrojů nachází právě na internetových stránkách. Ve velké míre se tak klíčovým zdrojem pro tento článek staly studie a články zveřejněné na internetových stránkách významných institucí, které se zabývají studiem evropské integrace a souvisejících oblastí (viz požitá literatura a zdroje).

Úkolu nalézt co nejpřesnější a nejvýstižnější definici pojmu europeizace se již věnovala řada autorů, rozsah této práce však nedovoluje zaměřit se na rozbor všech jednotlivých definic. ${ }^{2}$

1 Na počátku je nutné upozornit na rozdílné používání samotného pojmosloví. V českém prostředí se lze setkat s několika variantami: europeizace, evropeizace, europeanizace, evropeanizace, prričemž obdobná terminologická nejednost existuje i v anglosaském prostředí (Dančák, Fiala a Hloušek 2005: 12). V této práci bude používán český termín europeizace a anglický ekvivalent europeanization.

2 Viz naprríklad Featherstone a Radaelli (2003); Olsen 1996, 2005; Caporaso, Risse a Cowles (2003); Knill a Lehmkuhl (2001); Börzel (2002). 
Lze však konstatovat, že všechny definice mají společných několik zásadních aspektů: především uznávají klíčový rys procesu europeizace, kterým je jeho dynamičnost. Jedná se o proces, který se neustále vyvíjí, přináší nové a nové podněty, v každém okamžiku a pro každou oblast politiky nabývá rozličných forem a intenzity. Většina autorů se tak orientuje na otázky vlivu evropské integrace, kdy současně spolu s rozšiřování Evropské unie tento proces postupně, se stále větší intenzitou, zasahuje nové státy. $V$ neposlední řadě přichází s novými tématy, kterým dř́ve nebyla pozornost věnována vůbec, či právě jen na úrovni národních států.

Kevin Featherstone (Featherstone a Radaelli 2003: 20) vymezil několik klíčových témat, které se studiem procesu europeizace nejvíce souvisejí. Jedná se zejména o otázky, jak europeizace ovlivňuje zájmy a ideje, aktéry a instituce v rámci EU; jaký je dopad EU na politické procesy; jak významné je transnárodní učení se (transnational learning) v politických procesech; jak se aktéri v různých národních uskupeních vypořádávají s povinnostmi vyplývajícími z politik EU; jak adaptační tlak vede k politické konvergenci mezi státy v určitých oblastech a nikoli v jiných; jaký je dopad EU na instituce a způsoby vládnutí; jaký je dopad europeizace na subnárodní autority atd. Ačkoli se jedná o velmi složitá témata, jejichž třeba jen dílčí zodpovězení vyžaduje dlouhodobé zkoumání procesu europeizace v dané oblasti, měla by tato studie formulovat odpovědi na některé otázky relevantní z hlediska zkoumané politické oblasti.

Stejně jako tomu bylo s definicí pojmu europeizace, nabízí se i v prípadě snahy o vytvoření typologie tohoto procesu řada možných variant. Zmíním alespoň jednu z navržených typologií, a to Featherstoneovu (Featherstone a Radaelli: 2003: 5) typologii odvíjející se od velmi širokého chápání pojmu europeizace. V jeho pojetí se jedná o čtyři kategorie - historický proces, kulturní různorodost, institucionální přizpůsobení (adaptaci) a adaptaci politik a politických procesů. Tyto čtyři kategorie skutečně naznačují velmi široký náhled na otázku europeizace, přičemž prvé dvě odpovídají tzv. maximalistické interpretaci pojmu europeizace (tj. dopadu všech aspektů souvisejících s pojmem Evropa), druhé dvě naopak spíše minimalistickému pojetí, které je zaměřeno na zkoumání vlivu Evropské unie (příp. ES). Vzhledem $\mathrm{k}$ tématu této studie bude pozornost zaměřena zejména na dvě posledně zmíněné kategorie. Hovoříme-li o vzdělávání, není možné opominout skutečnost, na kterou Featherstone upozorňuje - z hlediska kategorie kulturní různorodosti ovlivnila europeizace v mezinárodním měřítku širší sociální aktivity, mezi něž náleží zejména vzdělávání, a to prostřednictvím šiřrení kulturních norem, idejí, identit a rámců chování. Avšak i přes nespornou zajímavost této oblasti se jedná více o otázku podstaty vzdělávání, jež jde současně nad rámec časového ohraničení této práce, která je zaměřena především na období členství ČR v Evropské unii, prípadně na relevantní časový úsek před vstupem ČR do EU.

\section{Kontext pojetí vzdělávání a vzdělávací politiky}

Pro uvedení kontextu této práce je nutné si uvědomit několik skutečností, které výrazně ovlivňují roli a postavení vzdělávací politiky v ČR. Skutečnost, že vzdělávání (respektive školství - jak se častěji v českém prostředí uvádí) je z hlediska politických stran jednou z nejméně „zajímavých“ oblastí, potvrzuje řada aspektů, jakými jsou povolební obsazování ministerského křesla, rozsah zájmu médií o politiku vzdělávání, rozsah věnovaný vzdělávání 
v programech politických stran a ve vládních prohlášeních a v neposlední řadě i pozice vzdělávání v rámci státního rozpočtu. $Z$ hlediska sledované oblasti je jen velmi málo témat, která by si jednotlivé politické strany mohly vzít za svá a přístupem k těmto tématům se vymezit vůči ostatním politickým stranám v rámci stranického soupeření.

Současně se jedná o velmi citlivou problematiku v tom ohledu, že každý jedinec (respektive lépe každý volič) vzdělávacím systémem prošel, pamatuje si jeho jednotlivá úskalí, avšak většina voličů nepovažuje objevující se problémy za natolik závažné (například ve srovnání s důchodovou reformou, daňovou politikou apod.), aby podporoval politickou stranu, která by jako klíčové téma postavila zásadní reformu vzdělávacího systému. Důvody lze hledat v historickém vývoji vzdělávací politiky ČR (Československa), v pozitivních výsledcích některých studií o českém vzdělávacím systému (např́klad z hlediska procenta předčasných odchodů ze škol či procenta osob s dokončeným vyšším sekundárním vzděláním dosahuje Česká republika jedněch z nejlepších výsledků; viz Modernising... 2006). Neaktivní pojetí vzdělávání politickými stranami tak odráží i uvedené skutečnosti. Přístup politických stran ke vzdělávací politice byl velmi dobře patrný při sestavování vlád po volbách v červnu roku 2006, zejména pak z hlediska nominace osoby na post ministra/ministryně školství, mládeže a tělovýchovy. První Topolánkova vláda byla sestavena jako menšinová vláda Občanské demokratické strany, kdy do křesla ministra školství usedl nestranický expert. Při sestavování druhé Topolánkovy vlády byly dlouhou dobu vedeny ostré diskuse o obsazení jednotlivých křesel v této vládě, posléze již bylo o kandidátech téměř rozhodnuto, avšak u resortu školství stále nebylo jasno. Rozhodně se však nehovořilo o souboji o tento post, který nakonec získala (dle počtu křesel v Poslanecké sněmovně) nejslabší strana koalice.

\section{Europeizace vzdělávací politiky $\mathbf{v}$ ČR}

Vzdělávací politika v ČR - její formování a implementace - podléhá řadě vlivů přicházejících zejména ze strany mezinárodních/nadnárodních organizací a subjektů. V rámci Evropy lze jmenovat především Evropskou unii, OECD, Radu Evropy, UNESCO, přičemž nutné je zmínit separátně i Boloňský proces, na jehož vývoji se podílejí i výše uvedené subjekty. Vzdělávací politika ČR je tak formována výše uvedenými subjekty/procesy, avšak $\mathrm{v}$ rozdílné míře a $\mathrm{v}$ rámci rozdílných procesů.

Rada Evropy (RE) se ve svých aktivitách zaměřuje především na ochranu lidských práv, parlamentní demokracie a zákonnosti a na podporu informovanosti o evropské identitě, jež je založena na společných hodnotách a zahrnuje rozdílné kultury. Tyto cíle jsou následně reflektovány i v aktivitách, které tato organizace implementuje v oblasti vzdělávání. Jedná se především o pojetí vztahu vzdělávání a podpory lidských práv a základních svobod, výchovu k demokratickému občanství, podporu vysokoškolského vzdělávání a výzkumu (zde se Rada Evropy podílí na Evropském prostoru vysokoškolského vzdělávání [European Higher Education Area] v kontextu Boloňského procesu) a v neposlední řadě o jazykovou politiku. Ačkoli se tedy ČR plně zapojuje do aktivit RE, jejich dopad je na národní úrovni spíše dílčí (tzn. v určitých oblastech vzdělávání), avšak nikoli systémový.

OECD se na straně druhé zaměřuje na otázky podpory ekonomického růstu, zaměstnanosti, finanční stability či zvyšování životního standardu, přičemž v rámci vzdělávání se 
orientuje zejména na sběr a vyhodnocování dat souvisejících s otázkami vzdělávání a vzdělání v členských zemích. Jednou z hlavních aktivit je pak rovněž publikace zpráv a ročenek, studií, př́ípadových studií a př́kladů dobré praxe, analýz z jednotlivých zemí, brožur a jiných materiálů, které jsou respektovány v celoevropském měřítku a slouží rovněž jako podklady pro výstupy Evropské komise. Strategie přijímané na národní úrovni tak většinou vycházejí z mezinárodních statistik publikovaných právě $\mathrm{OECD}$, čímž lze sledovat nepřímý dopad této organizace na podobu vzdělávacího systému v ČR.

Dvěma klíčovými procesy, které však ovlivňují vývoj vzdělávací politiky v ČR v největší míře, je Boloňský proces a evropská integrace/spolupráce. Boloňský proces má od roku 1999 velmi výrazný dopad na reformy prováděné v rámci vysokoškolského vzdělávání v ČR. Evropská unie pak do značné míry ovlivňuje vzdělávací systém v celé jeho šiři s tím, že $\mathrm{v}$ rámci vysokoškolského vzdělávání se hlásí $\mathrm{k}$ vizím Boloňského procesu, př́ípadně přichází z dalšími aktivitami souvisejícími v současné době především s Lisabonskou strategií. $\mathrm{Z}$ tohoto důvodu budou dvě následující kapitoly věnovány těmto procesům ve větším detailu.

\section{Proměna vysokoškolského vzdělávání v ČR v kontextu Boloňského procesu a evropské integrace}

Ačkoli obecně se tato studie věnuje pojetí vzdělávání v kontextu komplexního rámce celoživotního učení, z hlediska vývoje evropské spolupráce v oblasti terciárního vzdělávání je pro zvýšení srozumitelnosti vhodnější věnovat se vysokoškolskému vzdělávání separátně. Spolupráce $\mathrm{v}$ oblasti terciárního vzdělávání se primárně rozvíjela $\mathrm{v}$ rámci iniciativ Rady Evropy, UNESCO a OECD a až postupem času byla tato již započatá spolupráce dále rozvíjena na půdě ES/EU. V současné době tedy lze sledovat dva komplementární procesy rozvoje Evropského prostoru vysokoškolského vzdělávání, a to z hlediska dále postupujícího Boloňského procesu a současně z hlediska rozvíjející se spolupráce na půdě EU.

Prvním krokem pro rozvoj Evropského prostoru vysokoškolského vzdělávání v Evropě bylo přijetí Společné deklarace o harmonizaci výstavby Evropského systému vysokého školství, jež byla podepsána na Sorbonně v květnu 1998 ministry školství Francie, Německa, Itálie a Velké Británie. V deklaraci se uvedené země přihlásily $k$ vytvoření otevřeného prostoru vysokého školství v Evropě, jehož systém bude založen na strukturovaných programech, přičemž byly zdůrazněny préedevším první cyklus studia a uznávání titulů po absolvování tohoto cyklu jako klíčové prvky pro naplnění cíle uvedeného v deklaraci. Dále byla zmíněna nutnost rozvoje vysokoškolských institucí tak, aby byly schopny reflektovat požadavky a potřeby celoživotního vzdělávání, které se pro stále více lidí stává nutností. Za klíčovou byla považována mobilita vysokoškolských studentů a učitelů, mj. jako nezbytná součást skutečné evropské integrace. Jedním z hlavních cílů deklarace se tak stala vize, že každému vysokoškolskému studentovi bude umožněno strávit alespoň jeden semestr studia na některé zahraniční vysoké škole s tím, že domácí instituce mu toto studium uzná jako součást jeho studijního programu. K Sorbonnské deklaraci se posléze přihlásilo 31 evropských zemí - včetně České republiky -, a to v rámci Společného prohlášení k Evropskému prostoru vysokoškolského vzdělávání na setkání v Boloni v červnu 1999. Přijata zde byla Boloňská deklarace zaměřená na reformu vysokoškolských systémů za předpokladu spolupráce všech 
signatářských zemí. Boloňská deklarace neměla být považována za politické stanovisko, nýbrž za akční program pro dosažení prrijatých cílů, přičemž rámcovým cílem bylo/je vytvoření Evropského prostoru vysokoškolského vzdělávání. Deklarace obsahovala výčet dílčích priorit, mj. 1) implementaci jednotného a srozumitelného rámce pro získávání akademických hodností, 2) zavedení strukturovaného systému studia, jenž by byl rozčleněn do srozumitelných a srovnatelných stupňů (bakalárský, magisterský a doktorský), 3) zavedení Evropského systému přenosu kreditů (European Credit Transfer System - ECTS), 4) eliminaci přetrvávajících překážek bránících mobilitě studentů a pedagogických pracovníků a v neposlední řadě 5) rozvoj evropské spolupráce v zajištění kvality.

Boloňský proces se rozvíjel v průběhu posledních deseti let s tím, že každé dva roky byla uspořádána konference ministrů členských států, kteří v rámci přijatého komuniké definovali cíle rozvoje další spolupráce. Na konferenci ministrů v Praze (2001), Berlíně (2003), Bergenu (2005) a Londýně (2007) došlo k rozšiřrení témat/cílů spolupráce zemí Boloňského procesu např́klad o otázky zajištování kvality, celoživotního přístupu ke vzdělávání a podpory prostupnosti systému, sociálního rozměru Evropského prostoru vysokoškolského vzdělávání (především s ohledem na překážky bránící mobilitě a rozšiřování Boloňského procesu) či zaměstnatelnosti absolventů VŠ. Diskutován byl i tzv. externí rozměr Boloňského procesu, tj. vztah mezi Evropským prostorem vysokoškolského vzdělávání a ostatním světem. Na jednání v Bergenu rovněž došlo $\mathrm{k}$ přijetí dvou zásadních dokumentů, kterými jsou:

1) Rámec kvalifikací pro Evropský prostor vysokoškolského vzdělávání, který zahrnuje obecné deskriptory pro každý ze tř́ cyklů studia, jež jsou založené na výstupech ze vzdělávání, a soubor standardů, postupů a hlavních směrů v oblasti zabezpečení kvality;

2) Princip Evropského registru agentur pro zabezpečení kvality.

V současné době je mj. věnována pozornost otázce budoucího vývoje Boloňského procesu, respektive jeho podoby a cílů po roce 2010. Vzhledem ke skutečnosti, že vytvoření EHEA bylo koncipováno na období deseti let, je rok 2010 považován za př́ležitost pro přehodnocení vizí a cílů tohoto procesu.

Počátky iniciativ ES/EU v oblasti vysokoškolského vzdělávání je nutné hledat již v 80. letech 20. stol., nebot' v roce 1987 byl vyhlášen program ERASMUS, jehož se v současnosti účastní ročně více než 150000 osob. Při př́ležitosti oslav dvacetiletého výročí tohoto programu zhodnotil jeho vývoj předseda Evropské komise José Manuel Barroso následovně: „ERASMUS již přerostl své poslání pouhého vzdělávacího programu. Řadě studentů evropských vysokých škol nabízí první šanci žít v cizí zemi. Stal se již společenským a kulturním fenoménem. Jde o vynikající príílad toho, čeho může dosáhnout koordinace na evropské úrovni v oblasti vzdělávání..." Komisař odpovědný za vzdělávání a kulturu, Ján Figel', ho doplnil slovy, že „Erasmus zásadní měrou přispěl a nadále přispívá k otevírání vysokoškolských systémů zemí EU v mezinárodním i evropském měřítku“ („Erasmus...“ 2006). Významnější iniciativy vytvářené $\mathrm{v}$ rámci Evropské unie se datují zejména od doby schválení Lisabonské strategie, která dala do prrímé souvislosti rozvoj moderního a světu otevřeného vysokoškolského vzdělávání (včetně výzkumu, vývoje a inovací) s posílením konkurenceschopnosti a hospodářského růstu zemí EU. Lisabonská strategie věnuje zvláštní pozornost otázkám výzkumu, vývoje a inovací (hovoří o vytvoření Evropského prostoru výzkumu a inovací [European Area of Research and Innovation]) a současně roli vzdělávání v kontex- 
tu celoživotního učení. Právě vysokoškolské vzdělávání je společným jmenovatelem obou oblastí, nebot' na straně jedné napomáhá vytvoření znalostní ekonomiky (v rámci koncepce celoživotního učení), na straně druhé je zázemím pro rozvoj výzkumu a vývoje. Po průběžném hodnocení naplňování strategie $\mathrm{v}$ roce 2004 a provedení její revize zůstalo prioritní postavení vysokoškolského vzdělávání zachováno. V závěrech Evropské rady z března 2005 je mj. kladen důraz na zvýšení veřejných a soukromých investic do této oblasti a na modernizaci ř́izení univerzit. Lisabonská strategie se tak svým zaměřením na podporu znalostní ekonomiky stala impulsem pro rozvoj iniciativ zaměřených na oblast vysokého školství v rámci Evropské unie. Na obecný př́stup Lisabonské strategie navázala Evropská komise publikací několika sdělení, ${ }^{3}$ které se zabývají postavením a rozvojem vysokoškolského vzdělávání $\mathrm{v}$ rámci EU. Jedním z nejdůležitějších dokumentů přijatých Radou a EP je Doporučení k další spolupráci v zajišt’ování kvality ve VŠ vzdělávání z února 2006, které navazuje na doporučení Rady č. 98/561/ES ze dne 24. záŕí 1998 o evropské spolupráci v zajištění kvality ve vysokoškolském vzdělávání.

Jak již bylo zmíněno výše, Česká republika se zapojila do Boloňského procesu už v roce 1999 a okamžitě přijala cíle a vize tohoto procesu za své. Principy vytváření Evropského prostoru vysokoškolského vzdělávání se staly důležitým prvkem pro rozvoj vysokoškolského vzdělávání v ČR a byly plně zakomponovány do národních strategických dokumentů v oblasti vysokoškolského vzdělávání. Z legislativního hlediska bylo přijetí principů Boloňského procesu ošetřeno $\mathrm{v}$ Zákoně o vysokých školách z roku $1998^{4}$ a v př́slušných novelách z let 2001 a 2005. ${ }^{5}$ Zejména se jedná o definici třístupňového cyklu studia, jak byla přijata $\mathrm{v}$ rámci Boloňského procesu. Konkrétní implementaci procesu podchytilo Ministerstvo školství, mládeže a tělovýchovy v dlouhodobých záměrech a strategických dokumentech (koncepcích) $\mathrm{v}$ oblasti vysokých škol, ${ }^{6}$ přičemž přihlášení se $\mathrm{k}$ cílům Boloňského procesu bylo uvedeno již v Národním programu rozvoje vzdělávání v České republice (Bílá kniha) z roku 2000. Klíčovou roli v realizaci Boloňského procesu sehrává koncepce reformy vysokoškolského vzdělávání, jež byla vládou v roce 2004 přijata a o rok později aktualizována, respektive doplněna rozborem souladu cílů a nástrojů Strategie hospodářského růstu ČR a aktualizace koncepce reformy vysokého školství. Záměrem koncepce je, aby se vysoké školy rozvíjely „ke špičkové kvalitě (excelenci), zvýšily svoji konkurenceschopnost na evropské úrovni, popřr. výrazně vynikly na národní úrovni v některé ze svých činností - vzdělávací (včetně celoživotního vzdělávání), vědecké a výzkumné nebo tzv. servisní oblasti“ (viz Koncepce reformy vysokého školství - aktualizováno 2005). Mezi hlavní cíle koncepce, jež přímo reflektují vize Boloňského procesu, tak vedle zvýšení př́stupu k vysokoškolskému vzdělávání,

3 Viz Posílení spolupráce se třetími zeměmi v oblasti vysokoškolského vzdělávání (2001); Role univerzit v Evropě znalostí (2003); Mobilizace inteligence Evropy: umožnění univerzitám plně přispět k naplnění Lisabonské strategie (2005).

4 Zákon č. 111/1998 o vysokých školách a o změně a doplnění dalších zákonů.

5 Novela č. $147 / 2001$ a č. 552/2005.

6 Jedná se zejména o následující dokumenty: Strategie rozvoje terciárního vzdělávání (2000-2005), Koncepce reformy vysokého školství v Č́R (2004) a její aktualizace (2005), Dlouhodobý záměr vzdělávací a vědecké, výzkumné, vývojové, umělecké a další tvưrčí činnosti pro oblast vysokých škol pro období 2006-2010 a jeho Aktualizace pro rok 2006 a 2007. 
úspěšnosti a efektivity studia a zlepšení uplatnitelnosti absolventů náleží internacionalizace studia (tj. snaha zkvalitnit užívání evropského systému kreditů - ECTS, zajistit vydávání dodatku k diplomu ${ }^{7}$ a umožnit studentům realizovat alespoň jeden semestr v zahraničí); podpora studijních programů realizovaných v cizích jazycích; ${ }^{8}$ zajištění kvality studia prostřednictvím systematické podpory vnitřního hodnocení škol a postupného vybudování systému komplexního externího hodnocení; ${ }^{9}$ vytvoření národního rámce kvalifikací pro vysokoškolské vzdělávání kompatibilního s rámcem kvalifikací pro Evropský prostor vysokoškolského vzdělávání (přijat ministry školství na konferenci v Bergenu v květnu 2005). ${ }^{10} \mathrm{~V}$ rámci dlouhodobých záměrů v oblasti vysokého školství je z hlediska Boloňského procesu kladen důraz na následující aspekty: 1) rozšiřování nabídky studia v cizím jazyce, včetně zvyšování jazykové vybavenosti akademických pracovníků; 2) mezinárodní spolupráci v oblasti výuky; 3) podporu mobility studentů a akademických pracovníků; 4) rozvoj společných studijních programů (tzv. joint degrees); a 5) zavádění ECTS a vydávání dodatků k diplomu. Jednotlivé priority výše uvedených strategických dokumentů jsou následně realizovány zejména prostřednictvím vyhlašovaných rozvojových programů, kde mohou jednotlivé vysoké školy žádat o prostředky ze státního rozpočtu pro konkrétní rozvojové iniciativy.

Z hlediska jednotlivých cílů Boloňského procesu lze konstatovat, že dochází k realizaci všech iniciativ a principů definovaných v jeho rámci. Česká republika náleží mezi země, kde probíhá proces strukturování studia do tří cyklů, přičemž původní jednotný dlouhý cyklus zůstává v současnosti zachován pouze pro oblast lékařství a souvisejících oborů. ${ }^{11}$ Úspěšně probíhá i zavádění Evropského systému transferu kreditů na vysokých školách, vydávání dodatku k diplomu se v ČR stalo automatickou praxí, probíhá př́iprava na vytvoření národního rámce kvalifikací, jak byl definován v závěrech z konference v Bergenu v roce 2005. Plně podporován je rozvoj i tzv. joint degrees, a to ve všech třech cyklech studia. ČR rovněž naplňuje cíle v otázkách zajišt'ování kvality, jak je zmiňováno v principech Boloňského procesu i výše uvedených doporučeních Rady a EP. V neposlední řadě je nutné zmínit roli projektu Bologna Promoters, jehož cílem je podpora implementace vizí Boloňského procesu na národní úrovni a v jehož rámci byl vytvořen národní tým složený z expertů z resortu školství, vysokých škol a studentů, kteří společně poskytují vysokým školám konzultace, připravují

7 Cílem je, aby polovina veřejných vysokých škol a ty soukromé vysoké školy, které mají uzavřen tzv. „Erasmus University Charter“, získaly osvědčení Evropské komise „ECTS Label“ a aby všechny vysoké školy vydávaly dodatek k diplomu (při splnění podmínek Berlínského komuniké ze záŕí 2003) a získaly certifikát Evropské komise „Diploma Supplement Label“ (viz Koncepce 2005)

8 Do roku 2010 měl být podíl u doktorských studijních programů zvýšen z přibližně 30 \% na dvojnásobek, u magisterských studijních programů by měl tvořit polovinu.

9 Tyto aktivity již probíhají v rámci Boloňského procesu, přičemž ČR se jich aktivně účastní.

10 Evropský rámec kvalifikací je založen na výstupech, získaných kompetencích a profilech absolventů a využívá evropský systém kreditů (ECTS). Měl by být vytvořen jako základ pro prostupnost a uznávání získané odbornosti (včetně předchozí pracovní zkušenosti).

11 Pro srovnání: plná strukturace studia do tří cyklů proběhla zatím pouze ve zhruba 15 zemích Boloňského procesu. Ve většině zemí pak zůstává nestrukturovaný „dlouhý“ cyklus zachován pro obory medicíny a minimálně jeden další obor (většinou se jedná o obory architektury, práva apod.). 
semináře a konference, jsou zodpovědní za správu internetové stránky Boloňského procesu v ČR apod.

Na závěr této kapitoly je nutné zmínit otázku možného budoucího vývoje vysokého školství v ČR. V současnosti probíhá př́íprava Bílé knihy terciárního vzdělávání, na jejímž zpracování se pod vedením MŠMT podílí tým odborníků na terciární vzdělávání. Tuto iniciativu zde uvádím zejména $\mathrm{z}$ toho důvodu, že je vypracovávána $\mathrm{v}$ souladu se závěry tematického hodnocení terciárního vzdělávání, které provádí OECD. Takováto hodnocení jsou tak další cestou pro ovlivnění národních vzdělávacích systémů v souladu s evropskými/mezinárodními trendy.

\section{Rozvoj vzdělávací politiky v rámci Evropské unie}

Př̀i prozkoumání primárního práva ES/EU nalézáme pouze dva články zmiňující vzdělávání, přičemž zpočátku byly dokonce jen součástí článku ošetřujícího jinou problematiku, jež se vzděláváním souvisela. Vzhledem $\mathrm{k}$ citlivosti tématu vzdělávání na národní úrovni docházelo $\mathrm{k}$ prohloubení spolupráce $\mathrm{v}$ této oblasti využíváním jiných cest, než jaké představuje přímé vytvoření společné politiky a její zanesení do primárního práva ES/EU. Dodnes je podstatnou klauzulí prítomnou ve všech článcích smluv zmiňujících vzdělávání zdůrazňování toho, že Společenství v žádném případě nepodnikne jakákoli harmonizační opatření $\mathrm{v}$ této oblasti. Společenství proto hledalo jiné cesty pro ukotvení a prohloubení spolupráce ve vzdělávání. Našlo je v nezávazných politických prohlášeních, usneseních, zprávách apod., jež v průběhu let vytvořily konzistentní celek napomáhající rozvoji vzdělávání na evropské úrovni. V př́ípadě vzdělávání/vzdělávací politiky lze sledovat, že $\mathrm{v}$ rámci Společenství existují disproporce mezi legislativním zakotvením a skutečnou praxí, a rovněž že není možné porozumět současné podobě fungování Evropské unie z pouhého studia smluvních dokumentů. Počáteční nezohlednění (a pozdější skromné zmínění) oblasti vzdělávání v primárním právu Společenství nebránilo jejímu pozdějšímu rozšíření, a to do značných rozměrů, jak dokazují strategické dokumenty (zejména Lisabonská strategie), nařízení ke strukturálním fondům, rozsah komunitárních programů atd.

Prŕíčinami rozvoje evropské spolupráce ve vzdělávání byly zpočátku problémy s nezaměstnaností (v upadajících průmyslových odvětvích bylo nutné préekvalifikovat pracovní sílu tak, aby byl usnadněn přechod pracovníků do jiných odvětví) a s mobilitou pracovní síly (tj. především s uznáváním profesních kvalifikací a získaných zkušeností a dovedností, rovněž však se vzděláváním rodinných př́slušníků $\mathrm{v}$ jiných zemích tak, aby nebyli vystaveni překážkám, jako by byli cizinci a ne občany Společenství). V současné době se jedná zejména o socio-ekonomické a demografické výzvy, kterým Evropa/země EU čelí. Rozvoj lidských zdrojů, respektive vysoce kvalifikované a adaptabilní pracovní síly se jeví jako nutnost pro zajištění budoucího socio-ekonomického růstu a prosperity.

$\mathrm{V}$ rámci Evropské unie a oblasti vzdělávání je tak možné sledovat př́klon $\mathrm{k}$ využití tzv. soft law $w^{12}$, které se vyznačuje tím, že postrádá rysy závazku, uniformity či možnosti

12 Vzhledem k nevýstižnosti možného překladu budu pracovat s anglickými pojmy hard law a soft law. 
uvalení sankcí na aktéry. ${ }^{13}$ Přestože jsou tato „pravidla jednání“ kritizována za nedostatek jasnosti a přsesnosti, za to, že nemají prímý dopad a podkopávají legitimitu samotné Evropské unie, $\mathrm{v}$ poslední době sehrávají $\mathrm{v}$ rámci evropské integrace stále větší roli a jsou rozšiřována do řady procesů, nebot' disponují potenciálem pro reflexi rozdílnosti mezi členskými státy a možnými změnami. Častější využití soft law v evropské integraci lze dokázat na rozvoji Lisabonské strategie - členské státy se shodly na dodržování jednotných strategií a směrů př́ípravy a provádění reforem (viz Integrované směry pro růst a zaměstnanost,,$^{14}$ Evropská strategie zaměstnanosti, Směry pro politiku v oblasti financí a hospodářství [Broad Economic Policy Guidelines - BEPGs]), a to bez nutnosti využívání sankcí při jejich neplnění. Jednotlivé strategie mají přesně definovány priority, východiska, systém zpráv, monitoring, indikátory a v neposlední řadě možnost výměny zkušeností a př́kladů dobré praxe. A právě i posílení vlivu Evropské unie - respektive evropské spolupráce - ve vzdělávání v rámci Lisabonské strategie vychází ve velké míre z využití soft law, nebot' na rozdíl od aktů sekundárního práva, kde všechny členské státy bedlivě střeží své národní kompetence ve vzdělávací politice, rozšiřuje možnosti spolupráce bez prímého využití legislativních aktů. Př́íladem je shoda členských států nad společným zněním strategických/integrovaných směrů, ${ }^{15}$ které definují priority koncepce a provádění reforem v národních vzdělávacích politikách.

Využití soft law je oceňováno vzhledem $\mathrm{k}$ nižším nákladům na spolupráci, možnosti využití diverzity existující mezi členskými státy, flexibilitě, jednoduchosti, rychlosti v procesu schvalování a v neposlední řadě otevřenosti více aktérům. $Z$ výše uvedeného tedy vyplývá, že právě soft law otevírá velmi široký prostor spolupráce právě ve vzdělávání, jež je politikou výsadně rrízenou národními státy. Kromě podnícení této spolupráce navíc umožňuje propojit oblast vzdělávání s ostatními souvisejícími oblastmi a politikami (finance, hospodáŕství, zaměstnanost), a tím posílit její roli a dopad. $V$ př́ípadě vzdělávací politiky je klíčová zejména tzv. Otevřená metoda koordinace (Open Metod of Coordination - OMC), kterou lze charakterizovat jako jeden z př́kladů využití soft law v konkrétní politické oblasti. Tato metoda - narozdíl od Klasické metody Společenství (Classic Community Method - CCM) - předkládá členským státům obecné cíle a směry jednání (srovnej Trubek, Cottrel a Nance 2005). V praxi poskytuje široký rámec vyhovující různorodému prostředí států EU, rozvíjející možnost výměny zkušeností a prríkladů dobré praxe a současně napomáhající naplnit cíle definované na úrovni Evropské unie.

13 Francis Snyder (Trubek, Cottrel a Nance 2005) definuje soft law jako pravidla jednání, která v podstatě nemají právní sílu, ale která mají praktický dopad.

14 Integrované směry pro růst a zaměstnanost byly schváleny v roce 2005 a postupně procházejí kritickou revizí. Detailněji o nich bude pojednáno v části věnované prř́pravě Národního programu reforem v ČR.

15 V anglické terminologii se využívá pojem ,integrated guidelines“, v českém překladu se nejčastěji využívá termín (integrované) „směry“, méně často „vodítka“. 


\section{Proces europeizace vzdělávací politiky v ČR}

V rámci procesu europeizace můžeme z pohledu reakcí národních států rozlišit zejména dvě dimenze - na straně jedné jsou národní státy iniciátory vzniku evropských institucí a politiky na úrovni EU, na straně druhé reagují na procesy odehrávající se na úrovni EU (srovnej Börzel 2001). Z institucionálního hlediska lze z pohledu národních států na straně jedné rozlišovat proces vytváření nových politických struktur a procesů na úrovni Evropské unie, které jsou ve vzájemné interakci se strukturami a procesy prítomnými v rámci členských zemí EU, na straně druhé vliv, který mají výše uvedené instituce a procesy na národní státy a jejich instituce/struktury. Jedná se tak o dva př́stupy s rozdílnou perspektivou vývoje - první je zaměřen na procesy iniciované zdola („bottom-up approach“), druhý se soustředí naopak na iniciaci procesů směřujících shora dolů (,top-down approach“).

V kontextu procesu europeizace lze tedy z hlediska České republiky sledovat zejména tři roviny: institucionální reakce na proces europeizace vzdělávací politiky v rámci ČR, adaptace vzdělávací politiky ČR, reakce ČR v rámci evropské spolupráce.

Klíčovými hráči na poli vzdělávání v rámci EU jou Evropská komise, zejména generální ředitelství pro vzdělávání a kulturu (DG EAC), Evropský parlament, respektive Výbor pro vzdělávání a kulturu ${ }^{16}$ a Rada ministrů, která se schází ve formaci kultura, vzdělávání a mládež. ČR se na zapojení do Evropské unie a jejích struktur připravovala již před samotným vstupem, což platí i z institucionálního hlediska. Zejména se jednalo o zapojování do aktivit jednotlivých pracovních skupin, at’ již v rámci Rady EU či v rámci $\mathrm{EK}$, kde se zástupci ČR měli možnost seznamovat s jejich činností a připravovat se na plnohodnotné zapojení. Po vstupu ČR do EU však byla nutná př́má a okamžitá reflexe procesů odehrávajících se na úrovni EU z hlediska institucionálního zajištění samotného členství. Na národní úrovni byl ustaven Výbor pro EU, který byl platformou pro projednávání zásadních evropských záležitostí $\mathrm{s}$ celostátním dopadem. Výbor se schází každé úterý na úrovni náměstků jednotlivých resortů a klíčových institucí, od roku 2007 pak i na nejvyšší politické úrovni, což reflektuje zvyšující se dopad evropských záležitostí na jednotlivé politiky, strategie a instituce ČR a částečně i význam bližícího se předsednictví ČR v Radě EU. Výbor pro EU z hlediska vzdělávání zejména schvaluje instrukce pro jednání COREPERu, mandáty pro ministra/ministryni na jednání Rady EU, zapojení MŠMT do př́prav na předsednictví ČR v Radě EU aj. Zásadním procesem adaptace však prošlo zejména Ministerstvo školství, mládeže a tělovýchovy, které je za oblast vzdělávání a zapojení ČR do evropské spolupráce v této oblasti př́mo odpovědné. Klíčová je zde role Odboru pro záležitosti EU a mezinárodní vztahy, ${ }^{17}$ který je na MŠMT př́mo odpovědný za sledovanou oblast, její řádnou reflexi na národní úrovni a naopak za zapojení ČR v evropských institucích a strukturách. Pro řádné projednávání všech záležitostí s dopadem na národní úrovni byla zřízena tzv. Resortní koordinační skupina MŠMT, která je formována jako poradní orgán odpovědného náměstka a v níž se schází jak osoby odpovědné za národní politiky v oblasti vzdělávání v rámci resortu školství, tak osoby z jiných resortů, zástupci sociálních partnerů a jiných dotčených institucí.

16 V současné době je v něm ČR vedle náhradníků zastoupena dvěma poslanci - V. Flasarovou a T. Zatloukalem.

17 Jméno tohoto odboru se vícekrát měnilo, zde je použit aktuální název. 
Zásadním impulsem pro institucionální změny na MŠMT však byla možnost získání prostředků ze strukturálních fondů. Nutnost administrativního zajištění přípravy a implementace operačních programů se odrazila $\mathrm{v}$ transformaci resortu - na jedné straně bylo nutné dodržovat priority vládní koalice $\mathrm{z}$ hlediska snižování počtu státních úředníků, na straně druhé bylo/ je nutné zajistit rádnou administraci prostředků získaných ze strukturálních fondů. Tato skutečnost vyústila ve 1) vytvoření nové skupiny pod vedením nově ustaveného postu náměstka ministryně; 2) posílení již existující skupiny, do jejíž agendy spadaly od počátku i strukturální fondy, o dva nově vytvořené odbory. ${ }^{18}$ Uvedené změny v institucionální struktuře MŠMT byly doprovázeny postupnou adaptací agend a kompetencí téměř všech odborů. Jednotlivé iniciativy existující v rámci evropské spolupráce ve vzdělávání bylo nutné konfrontovat $\mathrm{s}$ národní vzdělávací politikou, bylo nutné získávat pozice a stanoviska k jednotlivým problematikám/dokumentům, zapojení do aktivit expertních skupin (clusterů) pod záštitou EK si vyžadovalo stále větší zapojení všech osob/odborů/skupin do evropské problematiky.

Z hlediska adaptace národní vzdělávací politiky lze na iniciativy odehrávající se na úrovni EU s dopadem na národní úroveň pohlížet v následujících rovinách:

1. strategicko-politická úroveň (sem náleží i přijímání a realizace různých legislativních akti̊),

2. realizace otevřené metody koordinace,

3. implementace komunitárních vzdělávacích programů a strukturálních fondů.

Nejvyšší, strategicko-politickou úroveň zastává z hlediska svého celoevropského působení a komplexního charakteru Lisabonská strategie. O této strategii toho bylo již mnoho napsáno, a tak se nebudu zabývat jejím detailním rozpracováním. I přes často kritický pohled na realizaci Lisabonské strategie jako celku je nutné analyzovat pozici a roli vzdělávání/ vzdělávací politiky $\mathrm{v}$ této strategii bez předsudků vycházejících z jejího celkového hodnocení. Přestože již před jejím schválením byla role vzdělávání označována za důležitou pro rozvoj kvalifikace všech osob a pro jejich zapojení do společnosti a pracovního procesu (viz koncept společnost znalostí/knowledge society), v rámci Lisabonské strategie získalo vzdělávání mnohem vyšší postavení, a to zejména s ohledem na podporu socio-ekonomického vývoje Evropy. Jakkoli nereálný se může zdát cíl stát se do roku 2010 nejkonkurenceschopnější, dynamickou ekonomikou založenou na znalostech, pro vzdělávací politiku otevřel široký prostor mezi ostatními politikami. A dále, ačkoli je ze strany mnoha osob považována Lisabonská strategie ve vzdělávání za pouhé rétorické a politické proklamace, získala si tato oblast i řadu nástrojů, jejichž prostřednictvím lze naplňovat většinu deklarovaných cílů - at' již jde o nové platformy spolupráce, nasměrování finančních tokủ do oblasti rozvoje lidských zdrojů či prrijímání legislativních aktů zaměřených na zkvalitnění vzdělávání v Evropě.

Významným krokem z hlediska vzdělávání bylo schválení tzv. integrovaných směrů pro růst a zaměstnanost. Tyto směry v sobě zahrnují principy reformních opatření ve všech relevantních oblastech. Je však nutné všimnout si jednoho aspektu: integrované směry zde vedle sebe staví politiky, které v rámci primárního práva nestojí na stejné úrovni (jedná se o oblasti s různou mírou kompetencí evropských institucí). Poslední dva „směry“ jsou pak věnovány

18 Viz internetové stránky MŠMT: www.msmt.cz (organizační struktura je dostupná na: http://www. msmt.cz/uploads/soubory/rganizacni_struktura/ELOrganizacnistrukturak01072007web.pdf) 
politice ocitající se výhradně v kompetenci národních států - vzdělávací politice. Ačkoli integrované směry nezakládají konkrétní povinnosti a neřeší otázky kompetencí, výraznou měrou zasahují do daných politik na národní úrovni, nebot' krokem následujícím po jejich přijetí bylo zpracování tzv. Národních programů reforem (NPR). Tyto programy (zpracované na období 2005-2008) přímo vycházejí z integrovaných směrů a identifikují klíčové reformy, mj. i v oblasti vzdělávací politiky. Klíčovým aspektem, který ještě více propojil evropskou úroveň s národní politikou, byl př́stup Evropské komise, která od počátku upozorňovala na skutečnost, že ze strukturálních fondů pro období 2007-2013 budou primárně financovatelné pouze priority uvedené současně v Národním programu reforem. Prostřednictvím Národních programů reforem tak došlo $\mathrm{k}$ úplnému provázání integrovaných směrů s vývojem národních politik, jejichž podobu pro nadcházející období ve velké míře ovlivňuje možnost získání prostředků ze strukturálních fondů. Jinak řečeno, do přímé souvislosti se tak dostaly tři aspekty: znění integrovaných směrů pro růst a zaměstnanost; čerpání prostředků ze strukturálních fondů a národní priority vzdělávací politiky ČR. Pro úplnost považuji za nutné doplnit pět priorit identifikovaných v oblasti vzdělávání v NPR: 1) realizace kurikulární reformy, 2) podpora spolupráce vzdělávacích institucí a zaměstnavatelů, 3) rozšíření přístupu k terciárnímu vzdělávání, 4) zlepšení propojení počátečního a dalšího vzdělávání a 5) podpora prostupnosti v terciárním vzdělávání.

Na základě schválené Lisabonské strategie a jejího politického zadání se postupně rozvíjely nové iniciativy a činnosti v oblasti vzdělávání a odborné př́ípravy. Klíčovým dokumentem, jenž byl ministry odpovědnými za vzdělávání přijat 14. února 2002, se stal dokument Vzděláváni a odborná př́prava v Evropě: Různé systémy, společné cíle do roku 2010 - Pracovni program formulujici cíle systémů vzděláváni a odborné př́pravy (ET 2010) ${ }^{19}$. Tento program definuje tři strategické cíle rozvinuté ve 13 dílčích cílech, jež mají být naplněny do roku 2010 a jež jsou zaměřeny na otázky kvality, efektivity a otevřenosti vzdělávacích systémů zemí EU. Na základě tohoto strategicko-politického dokumentu byla ze strany Evropské komise navržena řada dílčích iniciativ, jež prưřezově zasahovala do všech úrovní vzdělávání. Tyto návrhy a iniciativy Evropské komise se následně často promítly v přijetí legislativních aktů schválených Radou EU či v součinnosti s Evropským parlamentem. Dopad na národní politiku ve vzdělávání lze pak rozlišit v několika fázích - v první fázi, kdy je představena určitá problematika, mají členské státy možnost seznámit se s různými analýzami a podkladovými materiály, které obsahují cenné údaje a data využitelná i na národní úrovni. V další fázi jsou dokumenty na pracovní úrovni projednávány, přičemž členské státy mají možnost ovlivnit jejich konečnou podobu. Po schválení těchto dokumentů je však zásadní jejich implementace do národních politik. Ačkoli se v př́padě vzdělávání jedná především o doporučení či výzvy, a tedy politické závazky, u některých iniciativ jsou stanoveny i termíny, jejichž dodržení není povinné, avšak z politického hlediska panuje snaha o jejich zohlednění.

19 Detailed work programme on the follow-up of the objectives of Education and training systems in Europa: Work programme of the Education Council in cooperation with the Commission, February 2002 - dostupné na: http://europa.eu/eur-lex/pri/en/oj/dat/2002/c_142/c_14220020614en 00010022.pdf 
Z hlediska ČR nevyžadoval vstup do Evropské unie zásadní legislativní úpravy, spíše se jedná o reflexi výstupů evropské spolupráce ve strategicko-koncepčních dokumentech v oblasti vzdělávání. Např́klad nejzásadnější změnou v zákoně č. 561/2004 Sb., o předškolním, základním, středním, vyšším odborném a jiném vzdělávání, ve znění pozdějších předpisů, bylo doplnění §2, odst. 1a) o zásadu rovného přístupu každého státního občana jiného členského státu EU ke vzdělávání bez jakékoli diskriminace, včetně záruky bezplatného základního a středního vzdělávání. Z hlediska koncepčních dokumentů v oblasti vzdělávání je nutné zmínit, že již Národní program rozvoje vzdělávání v České republice (tzv. Bílá kniha $)^{20}$ schválený vládou na zasedání dne 7. 2. 2001 zmiňuje všechny výše uvedené subjekty působící v Evropě v oblasti vzdělávání, odkazuje se na dokumenty (zprávy, studie, koncepce) přijaté $\mathrm{v}$ rámci těchto subjektů a současně uvádí výzvy, které je nutné v ČR reflektovat, jež jsou však společné pro všechny evropské země. Ve zvláštní kapitole je pozornost věnována evropské a mezinárodní spolupráci ve vzdělávání, kdy aktivity ČR v rámci EU mají být zaměřeny na plnění úkolů a závazků vyplývajících z úsilí ČR o plné členství, spolupráci s členskými zeměmi EU, realizaci programů evropské spolupráce ve vzdělávání a př́ípravě na využivání strukturálních fondů EU (Bílá kniha 2001: 30-31). Po vstupu ČR do EU byla tato otázka řešena v Dlouhodobém záměru vzdělávání a rozvoje vzdělávací soustavy ČR schváleném v roce 2005. Zde jsou uvedeny hlavní trendy, jež má vzdělávací systém reflektovat a které jsou velmi podobné cílům Lisabonské strategie EU (srovnej Dlouhodobý záměr 2005: 9). Změny vzdělávacího systému, které jsou zde identifikovány, jdou ruku v ruce s trendy a koncepcemi diskutovanými $v$ rámci Evropské unie, jimiž jsou nové pojetí vzdělávání $\mathrm{z}$ hlediska celoživotního učení, změny $\mathrm{v}$ počátečním vzdělávání $\mathrm{v}$ rámci orientace na klíčové kompetence a rozvoj dalšího vzdělávání $\mathrm{v}$ kontextu rozmanitosti jeho poskytování $\mathrm{v}$ EU. Koncepce se rovněž prímo odkazuje na plnění programu ET 2010 (viz pozn. č. 24) a na cíle vytyčené v kontextu Lisabonské strategie: „Cíle Evropské unie ve vzdělávání a odborné př́ipravě a při realizaci celoživotního učení jsou zcela kompatibilní s cíli české vzdělávací politiky a s dosavadním vývojem“ (Dlouhodobý záměr 2005: 19).

Jednou z významných iniciativ $\mathrm{s}$ celonárodním dopadem na vzdělávání a vzdělávací politiku, jež se odvíjí od členství ČR v EU, je rovněž zpracování Strategie celoživotního učení. Evropská komise zveřejnila dvě sdělení týkající se celoživotního učení v zemích $\mathrm{EU},{ }^{21}$ na nichž bylo založeno i usnesení Rady k celoživotnímu učení z června roku 2002. Závěry Rady ministrů z roku 2004, které př́mo vyzývaly ke zpracování národních strategií celoživotního učení ve všech členských zemích EU do konce roku 2006, se však staly politickým závazkem, který se ČR rozhodla naplnit. A tak s ohledem na termín pro odeslání strategie EK byl zahájen proces zpracování této strategie, jednou z jejíchž priorit bylo reflektování evropských iniciativ. Strategie celoživotního učení byla schválena usnesením vlády 11. července 2007 č. 761 s tím, že implementační plán má být hotov do konce roku 2008.

20 Veškeré strategicko-koncepční dokumenty v oblasti vzdělávání v Č́R jsou dostupné na internetových stránkách MŠMT: www.msmt.cz

21 Making a European Area of Lifelong Learning a Reality (listopad 2001) a Memorandum k celoživotnímu učení (ř́jen 2000). 
Mezi aktuální témata, jež jsou následně reflektována v národní politice, náleží zejména problematika klíčových kompetencí pro celoživotní učení (na úrovni EU byl přijat tzv. Evropský rámec klíčových kompetencí pro celoživotní učení, který je kompatibilní s kurikulární reformou prováděnou $\mathrm{v}$ ČR a napomáhá tak rozvoji tohoto tématu na národní úrovni); problematika indikátorů a referenčních úrovní (z hlediska EU je relevantní pro měření pokroku v plnění Lisabonské strategie, na národní úrovni rozviŕila diskusi k otázkám relevantnosti některých indikátorů, podložení vzdělávací politiky výzkumy a šetřeními atd.), či Evropský rámec kvalifikací, který svým zaměřením na transparentnost v uznávání výsledků vzdělávání namíríil více světla na vznikající Národní soustavu kvalifikací a její rozšiření směrem k nejvyšším úrovním vzdělání.

Aspektem významně ovlivňujícím vytváření a podobu národní politiky je samozřejmě i praktická realizace Otevřené metody spolupráce, zejména z hlediska podpory výměny informací a zkušeností mezi tvůrci vzdělávací politiky na evropské úrovni. Účast českých zástupců na expertních/pracovních jednáních (clusterech) pod vedením EK samozřejmě pozměňuje pohled na určitou problematiku, umožňuje získávat nové zkušenosti s řešením určitých problémů, a tím přibližuje i př́istupy ke vzdělávání mezi členskými zeměmi EU a Evropskou komisí, jako (často) hlavním hráčem. Obdobnou funkci plní i účast v komunitárních vzdělávacích programech, které jsou rozvíjeny na úrovni EU již od 80. let. Na straně jedné jsou využívány programy věnované systémovým problematikám a účasti tvůrců vzdělávacích politik v jednotlivých projektech. Tvůrci těchto politik mají následně potenciál využívat získané zkušenosti na systémové (celonárodní) úrovni. Jako velmi prínosná z hlediska vzdělávacího systému je hodnocena i účast pedagogických pracovníků v jednotlivých programech. Zkušenosti z pobytu na zahraničních školách se u těchto pracovníků promítají do výuky, tj. nacházejí své využití v praxi.

Specifickou roli v celém procesu sehrávají strukturální fondy EU, které byly zmíněny již výše. Je nutné zmínit, že řada iniciativ a reformních kroků v rámci vzdělávacího systému Č̉ by se bez těchto prostředků neobešla. Př́íprava a realizace kurikulární reformy, která zásadně mění pojetí vzdělávání v ČR, je prostřednictvím systémových a národních projektů financována z operačního programu Rozvoj lidských zdrojů (financován z Evropského sociálního fondu). Na programovací období 2004-2006 navazuje i další období, které je ještě více zaměřeno na otázku investic do rozvoje lidských zdrojů a podporu celoživotního učení (viz Národní strategický referenční rámec ČR 2007) ${ }^{22}$.

\section{Závěr}

Europeizace je velice komplexním procesem, jejž lze sledovat na mnoha úrovních a v kontextu řady interakcí. $Z$ hlediska vzdělávací politiky České republiky lze jistě rozlišovat několik dimenzí definovaných např́klad K. Featherstonem, které pokrývají širokou škálu pojetí tohoto procesu - od historického hlediska až po otázku adaptace institucí a politik. Předložená studie se zaměřila na užší pojetí, které se orientuje na aspekty změn v otázkách institucionální struktury a institucionálních politik. Z hlediska evropského kontinentu

22 Dostupný na internetových stránkách Ministerstva pro místní rozvoj: www.mmr.cz 
lze sledovat interakce zejména mezi národní úrovní a nadnárodními subjekty, jakými jsou ve vztahu ke vzdělávání zejména OECD, Rada Evropy a v neposlední řadě Evropská unie.

Ačkoli se v současné době pohlíží na vzdělávání v komplexním pojetí celoživotního učení, při sledování procesu europeizace se jeví jako nanejvýš vhodné zabývat se problematikou vysokoškolského vzdělávání separátně. Zde klíčovou roli sehrává Boloňský proces zaměřený na vybudování Evropského prostoru vysokoškolského vzdělávání, do něhož se ČR plně zapojila a jenž tak zpětně velmi výrazně ovlivnil podobu vysokoškolského vzdělávání v ČR.

Zásadní vliv na podobu a rozvoj vzdělávacího systému má však v poslední době Evropská unie, a to i přes legislativní ošetření této politiky v rámci primárního práva ES/EU, které připisuje evropským institucím pouze doplňkovou roli. Proces europeizace v kontextu vývoje Evropské unie lze sledovat v několika dimenzích - zejména na úrovni strategicko-politické, legislativní, dále v kontextu realizace Otevřené metody koordinace a komunitárních programů ES/EU, a v neposlední řadě z pohledu implementace strukturálních fondů EU. Na všech těchto úrovních je možné analyzovat vcelku zásadní vývoj interakcí mezi ČR a EU v oblasti vzdělávací politiky, která je však z právního hlediska plně v kompetenci národních států. V oblasti vzdělávání proto své uplatnění nacházejí zejména tzv. soft law a politické závazky a finanční nástroje EU, jakými jsou komunitární programy a strukturální fondy.

\section{Literatura}

Börzel, T. A. 2002. States and Regions in the EU: Institutional Adaptation in Germany and Spain. Cambridge: Cambridge University Press.

Dančák, B.; Fiala, P.; Hloušek, V. 2005. Evropeizace: nové téma politologického výzkumu. Brno: Mezinárodní politologický ústav.

Featherstone, K.; Radaelli, C. M. (eds.) 2003. The Politics of Europeanization. Oxford: Oxford University Press.

Dočkal, V.; Fiala, P.; Kaniok, P.; Pitrová, M. (eds.) 2006. Česká politika v Evropské unii: Evropský integrační proces a zájmy České republiky. MU Brno: Mezinárodní politologický ústav.

Knill, Ch. 2001. Europeanisation of National Administrations: Patterns of Institutional Change and Persistence. Cambridge: Cambridge University Press.

Lippert, B.; Umbach, G. 2005. The Pressure of Europeanisation: From Post-Communist State Administrations to Normal Players in the EU Systém. Institut für Europäische Politik, Europäische Schriften 82, Baden-Baden: NOMOS.

Trubek, D. M.; Cottrell, P.; Nance, M. 2005. „Soft Law,“ „Hard Law,“ and European Integration: Toward a Theory of Hybridity. In J. Monnet Working Paper 02/05. New York: New York University.

\section{Internetové zdroje}

Börzel T. A. 2001. Pace-Setting, Foot-Dragging, and Fence-Sitting. Member State Responses to Europeanization, Queen's Papers on Europeanisation, č. 4/2001. [citováno dne 5/2007]. Dostupné z: http://www.qub.ac.uk/schools/SchoolofPoliticsInternationalStudiesandPhilosophy/FileStore/EuropeanisationFiles/Filetoupload,38434,en.pdf. 
„Erasmus slaví dvacetiny: Komise zahájí oslavy kulatých narozenin svého nejznámějšího vzdělávacího programu.“ " [citováno dne 6.12.2006]. Dostupné z: http://ec.europa.eu/education/erasmus20_en.html.

Modernising Education and Training: A Vital Contribution to Prosperity and Social Cohesion in Europe. 2006 (Průběžná společná zpráva Rady a EK k pokroku v naplňování pracovního programu ET 2010, únor 2006. Dostupné z: http://eur-lex.europa.eu/LexUriServ/site/ en/oj/2006/c_079/c_07920060401en00010019.pdf

Olsen, J. P. 2005. The Political Organization of Europe: Differentiation and Unification, ARENA, Centre for European Studies, University of Oslo, Working paper No. 23. [citováno dne 5/2007]. Dostupné z: http://www.arena.uio.no/publications/working-papers2005/ papers/wp05_23.pdf.

Klićové koncepční a legislativni dokumenty v oblasti vzdělávání v ČR: ${ }^{23}$

Národní program rozvoje vzdělávání v České republice (Bílá kniha) (2001).

Dlouhodobý záměr vzdělávání a rozvoje vzdělávací soustavy ČR (2005).

Strategie rozvoje terciárního vzdělávání (2000-2005).

Koncepce reformy vysokého školství v ČR (2004) a její aktualizace (2005).

Dlouhodobý záměr vzdělávací a vědecké, výzkumné, vývojové, umělecké a další tvưrčí činnosti pro oblast vysokých škol pro období 2006-2010 a jeho Aktualizace pro rok 2006 a 2007.

Zákon č. 561/2004 Sb., o předškolním, základním, středním, vy̌̌ším odborném a jiném vzdělávání, ve znění pozdějších předpisů.

Zákon č. 111/1998 Sb., o vysokých školách a o změně a doplnění dalších zákonů, ve znění pozdějších predpisů.

Zákon č. 179/2006 Sb., o ověřování a uznávání výsledků dalšího vzdělávání a změně některých zákonů.

\section{Autorka}

Leona Šteigrová je studentkou doktorského studijního programu politologie na Fakultě sociálních studií MU. Zaměřuje se na otázky evropské integrace, zejména z hlediska rozvíjející se evropské politiky ve vzdělávání a rolí a aktivit jednotlivých institucí v této oblasti, v níž i profesně působí.

Kontakt: steigrova.leona@seznam.cz

23 Dostupné na internetových stránkách MŠMT: www.msmt.cz. 